\title{
Status and conservation of avian fauna of Sultanpur National Park Gurgaon, Haryana (India)
}

\section{G irish Chopra, Anil K . Tyor, Seema K umari* and Deepak Rai}

Department of Zoology, Kurukshetra University, Kurukshetra- 136119 (Haryana), INDIA

*Corresponding author. E-mail: sk.suthwal@gmail.com

Received: J uly 17, 2012; Revised received: J uly 27, 2012; Accepted: September 1, 2012

\begin{abstract}
The present study was conducted in Sultanpur National Park Gurgaon, Haryana (India) from February, 2011 to January, 2012 to analyze the avian diversity along with its status and abundance. During the study period, a total of 113 species of birds belonging to 14 orders, 35 families and 80 genera were identified. Maximum 41 species belonging to 12 families of order Passeriformes represented $36.28 \%$ of the total identified avian fauna while Podicipediformes and Strigiformes were the least represented avian orders (0.88\%) with one species each, namely, Little Grebe, Tachybaptus ruficollis and Spotted Owlet, Athene brama respectively. Out of total reported 113 species, 64 were 'resident' species and 49 were 'migrant' species. Most of the migratory species were winter visitors except Red throated flycatcher, Ficedula parva; Orange Headed Thrush, Zoothera citrine and Eurasian Golden Oriole, Oriolus oriolus which were summer visitors. In all, 42 species were 'common', 33 species were 'uncommon' and 38 species were 'occasional' bird species. Based on sighting, White Breasted Kingfisher, Halcyon smyrnensis; White Breasted Water Hen, Amaurornis phoenicurus; Common Moorhen, Gallinule chloropus; Black Wing Stilt, Himantopus himantopus; Red Wattled lapwing, Vanellus indicus; Cattle Egret, Bubulcus ibis and Indian Pond Heron, Ardeola grayii were common wetland bird species of Sultanpur National Park while Pied king fisher, Ceryle rudis and Coppersmith Barbet, Megalaima haemacephala were 'rarely sighted' bird species. During the study period, 7 'globally threatened' species, namely, Painted Stork, Mycteria leucocephala; Black neck Stork, E phippiorhynchus asiaticus; Black headed Ibis, Threskiornis melanocephalus; Darter, Anhinga melanogaster; Pacific Reef Egret, Egretta sacra; Sarus Crane, Grus antigone alongwith Hogson bushchat, Saxicola insignis were also recorded from the study area.
\end{abstract}

Keywords: Abundance, Avian fauna, Muscicapidae, Podicipedidae, Sultanpur National Park

\section{INTRODUCTION}

India is unique in having approximately 1300 species of birds constituting $13 \%$ of the world bird assembly and, thus, is a region of high avian diversity (Grimmett et al., 1998). Information about avian distribution across different habitats including protected areas (wildlife sanctuaries and national parks) in India is documented very well (Ali and Ripley, 1983; Gole, 1987; Ripley, 1988; Lainer, 1990; Naoroji, 1990; Pittie, 1990; Sinha and Mukherjee 1995; Javed and Rahmani, 1998; Kalsi 1998; Inskipp et al., 1999; Bhatt and Sharma, 2002; Choudhary, 2003; Srinivasan and Prashanth, 2005; Sundar, 2005; Urfi et al., 2005; Shahabuddin et al., 2006; Sultana et al., 2007; Pande et al., 2007).

Avifauna is important part of ecosystem as birds act as scavengers, pollinators, and predators of insect pests. They are also the good indicators of water ecosystem (Sinha and Mukherjee, 1995). Pioneer work on avian diversity has also been conducted by many researchers in the state of Haryana (Whistler, 1915 and 1918; Yadav and Maleyver, 1978 and 1981; Gupta and Ahmed, 1993; Gupta and Bajaj, 1997 and 1999; Kalsi, 1998; Harris, 2001;
Harvey, 2003). However, protected areas of Haryana have not been thoroughly explored from biodiversity point of view. Therefore, the present study was planned in Sultanpur National Park, Haryana to study avian diversity along with seasonal variations in their status and conservation strategies.

\section{MATERIALS AND METHODS}

Sultanpur National Park ( $28^{\circ} 28^{\prime} \mathrm{N}$ latitude and $76^{\circ} 53^{\prime} \mathrm{E}$ longitude) is located in a predominantly agricultural landscape crisscrossed by irrigation canals (Fig. 1). The national park covers an area of 13,727 ha (Islam and Rahmani, 2004) and includes its core area of 143 ha of low-lying marshes, notified as a bird sanctuary by the Haryana state government in 1971 (Kalpavriksh, 1994).

Periodic fortnightly visits were conducted from February, 2011 to January, 2012 in terrestrial and aquatic habitat in the area in the morning phase (06:00 AM to 10:00 AM) and later in the evening phase (15:00 PM to 18:00 PM) to record avian species, their status and conservation strategies. The birds were photographed using Sony Handycam model DCR-HC-42E and digital camera Nikon L-120 and were later identified following field guides (Ali ISSN : 0974-9411 (Print), $2231-5209$ (Online) All Rights Reserved @ Applied and Natural Science Foundation www.ansfoundation.org 


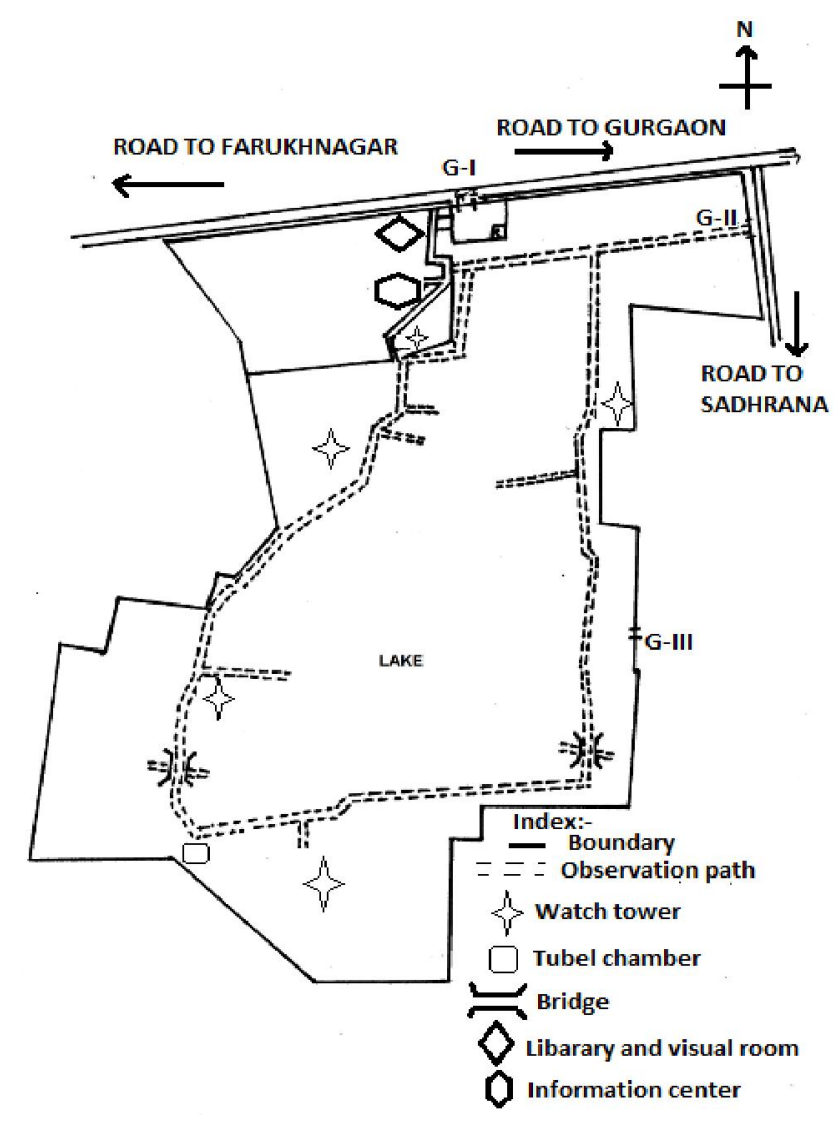

Fig. 1. Map showing the area and location of Sultanpur $\mathrm{Na}$ tional Park, G urgaon, Haryana.

and Ripley, 1987; Grimmett et al., 1998; Inskipp et al., 1999). Line transects method (Sale and Berkmuller, 1988) and point count method (Blondel et al., 1981) were used to study the avifauna.

Seasonal variations in avian diversity were recorded by collecting the data during winter, summer, monsoon and autumn seasons. The observed birds were categorized as A- abundant; C- common; O- occasional; U-uncommon and $\mathrm{Rr}$ - rare. Status of the birds were classified as: Rresident species, found in the study area throughout the year; WM- winter migrant species, found in the study area only in winter season; LM- local migrant species, found irregularly in study site but resident of India; BMbreeding migrant species, visiting the area for breeding or during the breeding seasons; SS- straggler bird species, observed at irregular gaps of the year in the study area; SU- status unknown species, not observed in above mentioned categories included in this category.

\section{RESULTS AND DISCUSSION}

Sultanpur National Park, known for low lying marshes and forest patches, harbours rich avian diversity (Gaston, 1994; Islam and Rahmani, 2004; Urfi et al., 2005). The region is known as suitable nesting site especially for Painted Stork, M ycteria leucocephala (Urfi et al., 2007). In the one year study from February, 2011 to January,
2012, a total of 113 species of birds belonging to 14 orders, 35 families and 80 genera were identified in the Sultanpur National Park. Avian diversity alongwith abundance, status and percentage composition is presented in Tables 1and 2.

Maximum of 41 species belonging to 12 families of order Passeriformes represented $36.28 \%$ of the total identified avian fauna in the present study. Podicipediformes and Strigiformes were the least represented avian orders $(0.88 \%)$ with one species each, namely, Little Grebe, Tachybaptus ruficollis and Spotted Owlet, Athene brama respectively. Most of the birds were observed near the wetland area and between the water islands. During the study period, 7 globally threatened species were also recorded. Among these, Painted Stork, Mycteria leucocephala; Black neck Stork, Ephippiorhynchus asiaticus; Black headed Ibis, Threskiornis melanocephalus; Darter, Anhinga melanogaster; Pacific Reef Egret, Egretta sacra are listed in 'near threatened' category and Sarus Crane, Grus antigone alongwith Hogson bushchat, Saxicola insignis are listed in 'vulnerable' category (IUCN, 2010). However, Gupta and Bajaj (1997) reported 8 globally threatened species including woolly-necked stork, Ciconia episcopus.

The family Muscicapidae of order Passeriformes dominated the list with 16 species and represented $14.15 \%$ of the total reported bird species. Out of total reported 113 species, 64 were 'resident' species and 49 were 'migrant' species. Most of the migratory species were 'winter visitors' except Red throated flycatcher, Ficedula parva; Orange Headed Thrush, Zoothera citrine and Eurasian Golden Oriole, O riolus oriolus which were 'summer visitors'. The past studies also revealed 44 winter migrant species (Gaston, 1994; Gupta and Bajaj, 1997).

The study revealed that out of total 113 birds' species, 33 species were 'uncommon', 42 species were 'common' and remaining 38 were 'occasional' species. Based on frequency of sightings, 7 species, namely, white breasted kingfisher, Halcyon smyrnensis; White Breasted Water Hen, Amaurornis phoenicurus; Common Moorhen, Gallinula chloropus; Black Wing Stilt, Himantopus himantopus; Red Wattled lapwing, Vanellus indicus; Cattle Egret, Bubulcus ibis and Indian Pond Heron, Ardeola grayii were 'common wetland' bird species of Sultanpur National Park. Black neck Stork, Ephippiorhynchus asiaticus; Black Headed Ibis, Threskiornis melanocephalus; Cotton Pygmy Goose, Nettapus cor omandelianus; Sarus Crane, G rus antigone; Common Red Shank, Tringa tetanus and Yellow Crowned Woodpecker, Dendrocopos mahrattensis were among the most 'uncommon' species and Pied king fisher, Ceryle rudis and Coppersmith Barbet, Megalaima haemacephala were 'rarely sighted' bird species. These 


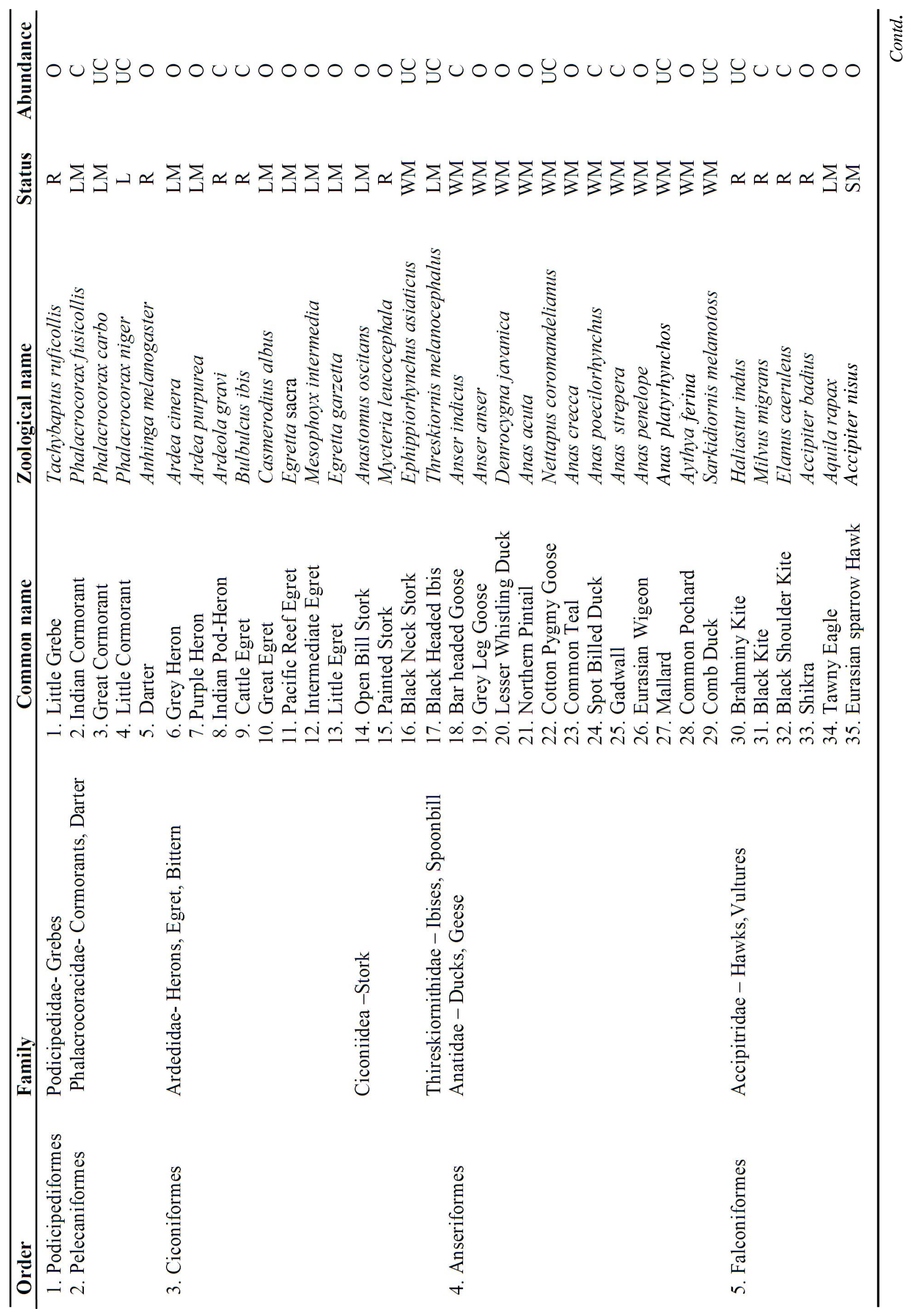




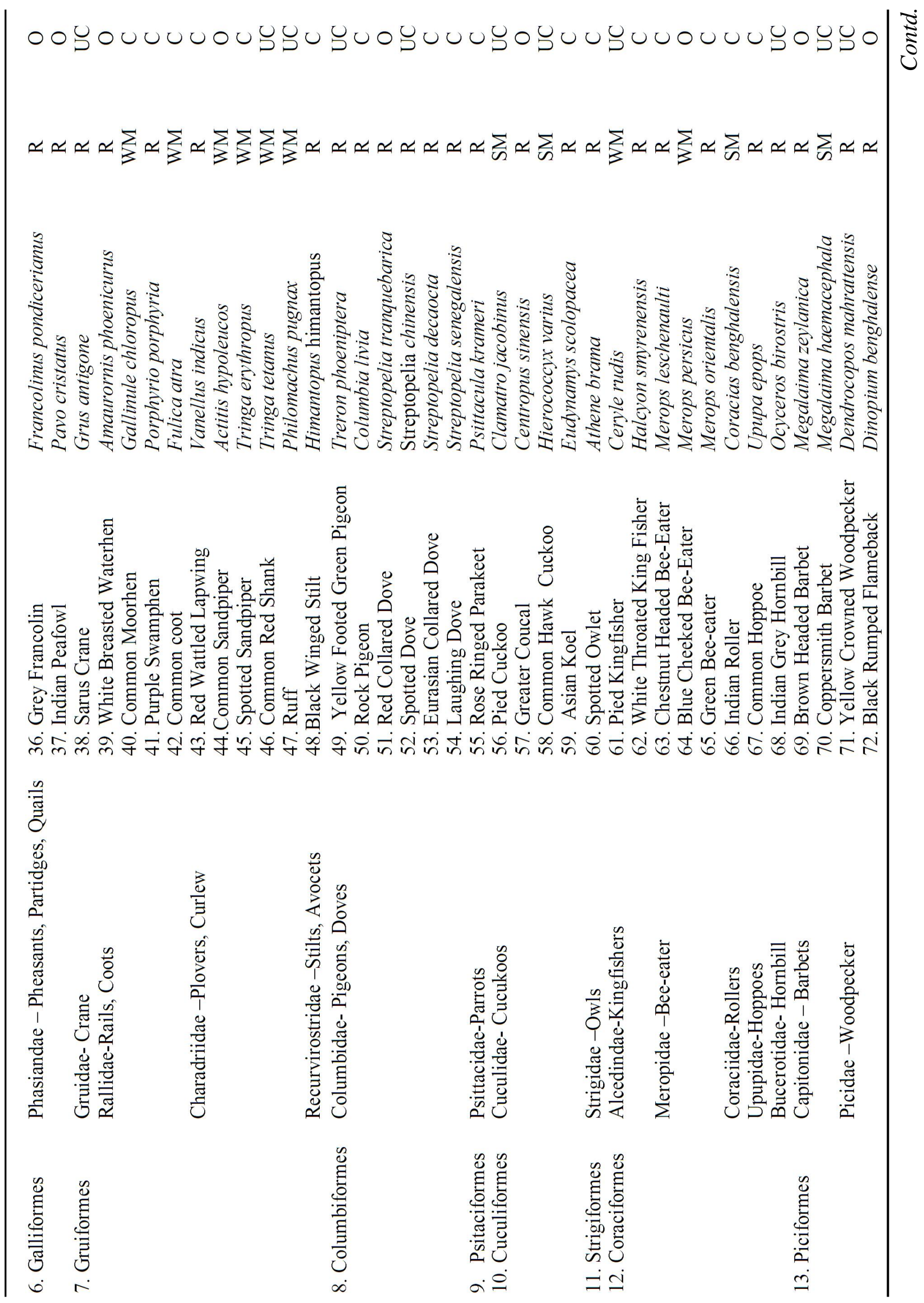




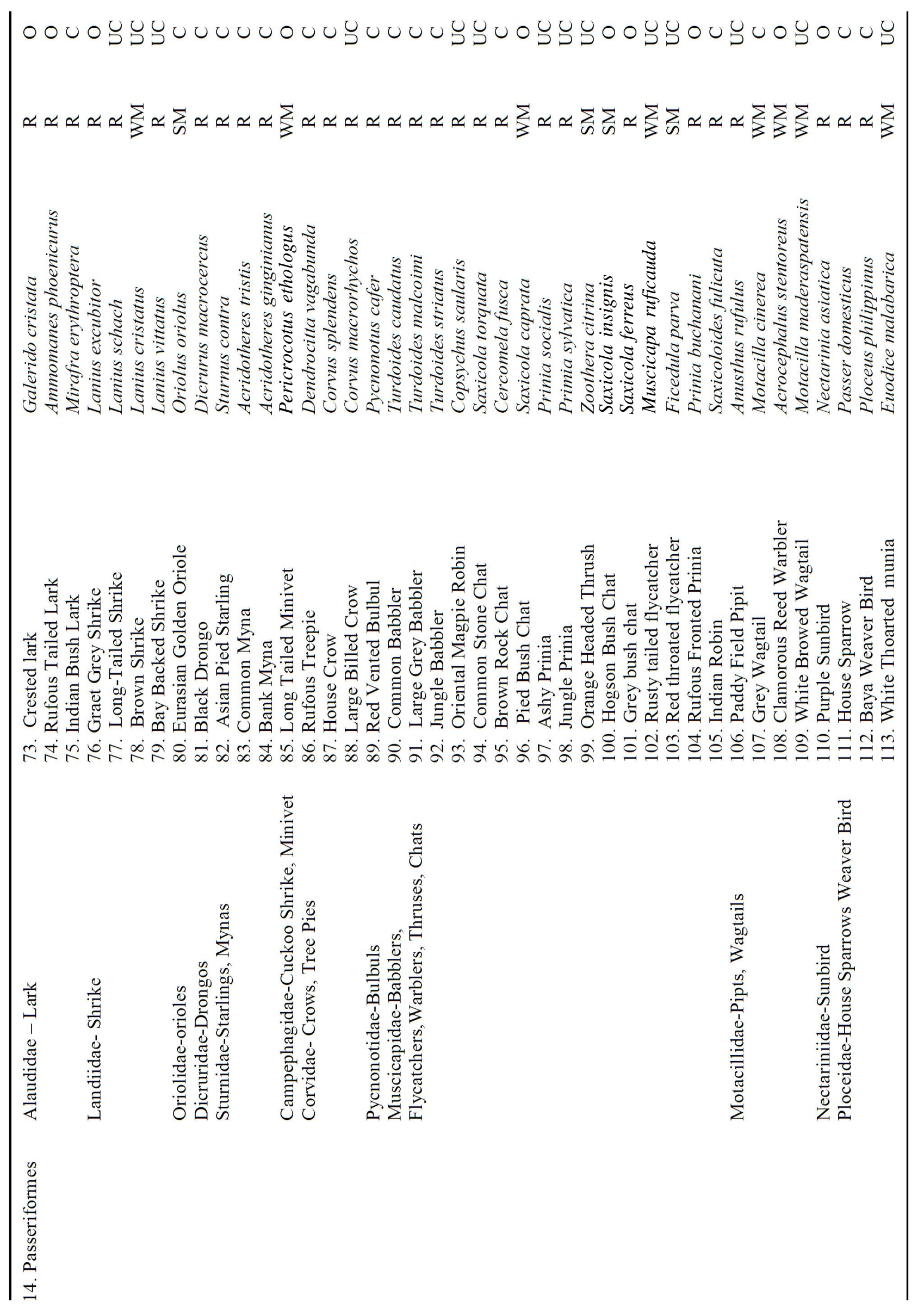


Table 2. Showing number (per cent) of avian species belonging to different orders and families.

\begin{tabular}{|c|c|c|c|c|}
\hline $\begin{array}{l}\text { Sr. } \\
\text { No. }\end{array}$ & Order & $\begin{array}{c}\text { No. of species } \\
(\%)\end{array}$ & Family & $\begin{array}{c}\text { No. of species } \\
(\%)\end{array}$ \\
\hline 1 & Anseriformes & $12(10.61)$ & Anatidae & $12(10.61)$ \\
\hline \multirow[t]{3}{*}{2} & Ciconiformes & $12(10.61)$ & Ardedidae & $8(7.07)$ \\
\hline & & & Ciconiidea & $3(2.65)$ \\
\hline & & & Thireskiornithidae & $1(0.88)$ \\
\hline 3 & Columbiformes & $6(5.30)$ & Columbidae & $6(5.30)$ \\
\hline \multirow[t]{5}{*}{4} & Coraciformes & $8(7.07)$ & Alcedindae & $2(1.76)$ \\
\hline & & & Meropidae & $3(2.65)$ \\
\hline & & & Coraciidae & $1(0.88)$ \\
\hline & & & Upupidae & $1(0.88)$ \\
\hline & & & Bucerotidae & $1(0.88)$ \\
\hline 5 & Cuculiformes & $4(3.53)$ & Cuclidae & $4(3.53)$ \\
\hline 6 & Falconiformes & $6(5.30)$ & Accipitridae & $6(5.30)$ \\
\hline 7 & Galliformes & $2(1.76)$ & Phasiandae & $2(1.76)$ \\
\hline \multirow[t]{4}{*}{8} & Gruiformes & $11(9.73)$ & Gruidae & $1(0.88)$ \\
\hline & & & Rallidae & $4(3.53)$ \\
\hline & & & Charadriidae & $5(4.42)$ \\
\hline & & & Recurvirostridae & $1(0.88)$ \\
\hline \multirow[t]{12}{*}{9} & Passeriformes & $41(36.28)$ & Alaudidae & $3(2.65)$ \\
\hline & & & Landidae & $4(3.53)$ \\
\hline & & & Oriolidae & $1(0.88)$ \\
\hline & & & Dicruridae & $1(0.88)$ \\
\hline & & & Sturnidae & $3(2.65)$ \\
\hline & & & Camephagidae & $4(3.53)$ \\
\hline & & & Pycnonotidae & $1(0.88)$ \\
\hline & & & Mucicapidae & $16(14.15)$ \\
\hline & & & Motacillidae & $4(3.53)$ \\
\hline & & & Nectariniidae & $1(0.88)$ \\
\hline & & & Corvidae & $3(2.65)$ \\
\hline & & & Ploceidae & $3(2.65)$ \\
\hline 10 & Pelecaniformes & $4(3.53)$ & Phalacrocoracidae & $4(3.53)$ \\
\hline \multirow[t]{2}{*}{11} & Piciformes & $4(3.53)$ & Capitonidae & $2(1.76)$ \\
\hline & & & Picidae & $2(1.76)$ \\
\hline 12 & Podicipediformes & $1(0.88)$ & Podicipedidae & $1(0.88)$ \\
\hline 13 & Psitaciformes & $1(0.88)$ & Psittacidae & $1(0.88)$ \\
\hline 14 & Strigiformes & $1(0.88)$ & Strigidae & $1(0.88)$ \\
\hline
\end{tabular}

two rare bird species are highly susceptible to habitat disturbances and, therefore, are good indicators of aquatic habitats (Kushlan, 1992; Jayson and Mathew, 2002; Kler, 2002). However, previous studies revealed 58 occasional species and 44 uncommon species (Gupta and Bajaj, 1999; Harvey, 2003; Islam and Rahmani, 2004). The rich diversity of the birds, documented during the present study, may be because of availability of the varied habitats including forest patch, low laying marshy areas as well as availability of different sources of food. The landscape has a large variety of flora including prominent trees (e.g., Prosopis juliflora, Acacia nilotica, Tamarindus indica and Azadirachta indica) and grasses (e.g., Vetiveria zizanioides and Erianthus ravennae). In addition, 'submerged vegetation' such as Vallisneria natans and Ceratophyllum demersum, 'emergents' such as Typha angustata, Saccharum munja and Cyperus rotundus, and 'surface vegetation' such as Nymphaea stellata, N. nouchali and Ipomoea reptans in the littoral zone of low laying water bodies provided feeding and/or roosting sites for small bird species (Urfi et al., 2005).

Increased anthropogenic factors such as habitat fragmentation and destruction, tourism pressure and scarcity of water in low lying water bodies during the summer season were some of the major stress factors posing threats to avian fauna in Sultanpur National Park. The herds of Nilgai, dog and wild cattle also occasionally trampled the chicks and eggs of water birds. It is, therefore, suggested that the water body needs to be patrolled regularly to minimize the disturbance, particularly during the breeding season. 


\section{REFERENCES}

Ali, S. and Ripley, S.D. (1983). Pictorial guide to the birds of Indian subcontinent. Delhi: Oxford University Press.

Ali, S. and Ripley, S.D. (1987). Compact handbook of the birds of India and Pakistan. Delhi: Oxford University Press.

Bhatt, D. and Sharma, R. (2002). Diversity, status and feeding Ecology of avian fauna in area of Rajaji National Park, India. Annals of Forestry, 2: 141-179.

Blondel, J., Ferry, C. and Frochot, B. (1981). Point counts with unlimited distance. Stud. Avian Biol., 6: 414-420.

Chaudhary, A. (2003). Birds of Eagle nest wildlife sanctuary and Sessa Orchid Sanctuary, Arunachal Pradesh, India. Forktail, 19: 1-13.

Gaston, A. J. (1994). Some comments on the revival of Sultanpur lake.Oriental Bird Club Bull., 20: 49-50.

Gole, P. (1987). Birds of the Kedarnath Muskodeer Sanctuary, Chamoli district, Uttanchal: status and distribution. J. Bombay Nat. Soc., 83: 603-617.

Grimmet, R., Inskipp, T. and Inskipp, C. (1998). Birds of the India subcontinent. Oxford University Press, Delhi.

Gupta, R.C. and Ahmed, I. (1993). On the clutch size, egg laying schedule, hatching patterns and stay of nestlings of Indian Hoopse, (U pupa epops). Geobios, 20: 148-150.

Gupta, R.C. and Bajaj, M. (1997). Preliminary investigations into migratory wetland birds of Brahma Sarovar at Kurukshetra. J eevanti, 15: 29-41.

Gupta, R.C. and Bajaj, M. (1999). An analysis of Ecological and behavioral patterns of migratory Shoveller (Anas clypeata, Linnaeus) in certain wetlands of Haryana. J eevanti, 17: $27-35$.

Harris, C. (2001). Checklist of the birds of Yamuna River (Okhla to Jaitpur village). Unpublished checklist downloaded January 2002 from http/www.delhibird.org/checklist/ checklists-yumna.htm.

Harvey, B. (2003). Checklist of the birds of Sultanpur. Retrieved August, 18, 2010 from http://www.delhibird.net/content/ view/73/89.

Inskipp, C., Inskipp, T. and Grimmet, R., (1999). A Pocket Guide to the Birds of the Indian Subcontinent.

Islam, M.Z. and Rahmani, A.R. (2004). Important Bird Areas in India: Priority sites for conservation. Mumbai and Cambridge, U.K.: Bombay Natural History Society and Bird Life International.

IUCN. (2010). IUCN Red List of threatened species. Version 2010. <www.iucnredlist.org.>

Javed, S. and Rahmani, A.R. (1998). Conservation of the avifauna of Dudhwa National Park, India Forktail, 14: 57-66.

Jayson, E.A. and Mathew, D.N. (2002). Structure and composition of two bird communities in the southern Western Ghats. J. B ombay Nat. H ist. Soc., 99(1): 8-25.

Kalpavriksh, (1994). Small and beautiful Sultanpur National Park. New Delhi.

Kalsi, R.S. (1998). Birds of Kalesar Wild Life Sanctuary,
Haryana, India. Forktail, 13: 29-32.

Kler, T.K. (2002). Bird species in Kanjali wetland. Tiger Paper, 39(1): 29-32.

Kumar, A., Sati, J.P., Tak, P.C. and Alfred, J.R.B. (2005). Handbook on Indian wetland birds and their conservation. Zoological Survey of India, Dehradun.

Kushlan, J.A. (1992). Population biology and conservation of colonial water birds. Colonial Water Birds, 15:1-7.

Lainer, H. (1990). The birds of Goa. J . B ombay Nat. His. Soc., 96(3): 405-423.

Naoroji, R. (1990). Predation by Aquila eagles on nestling storks and herons in Keoladeo National Park, Bharatpur. J. Bombay N at. His. Soc., 87: 37-46.

Pande, S., Sant, N., Ranande, S., Pednekar, S., Mestry, P., Kharat, S. and Deshmukh, V. (2007). Avifaunal survey of Andemaan and Nicobar Islands. Indian Birds, 3(5): 162-180.

Pittie, A. (1990). Checklist of birds of Calicut University campus Kerala. Indian Birds, 3(6): 210-217.

Ripley, S.D. (1988). A synopsis of Birds of India and Pakistan. Bombay Nat. His. Society.

Sale, J.B. and Berkmuller, K. (1988). Manual of wildlife techniques for Indian field documents no. 11. Wildlife Institute of India, Dehradun.

Shahabuddin, G., Kumar, R. and Verma, A. (2006). Annotated checklist of the birds of Sariska Tiger Reserve, Rajasthan, India. Indian Birds, 2(3): 71-76.

Sinha, S.P. and Mukherjee, S.K.. (1995). The management of Palamau Tiger Reserve: A report- Wildlife Institute of India, Dehradun.

Srinivason, U. and Prashanth, N.S. (2005). Additions to the avifauna of the Biligirirangan Hills, Karnataka. Indian Birds, 1(5): 103-104.

Sultana, A., Hussan, M.S. and Khan, J.A. (2007). Proposed Naina and Pindari wildlife sanctuaries in the Kumaon. Himalaya, Uttrakhand, India.J . B ombay Nat. H is. Soc., 104 (10): 19-29.

Sundar, K.S.G. (2005). Predation of fledgling Painted Stork Mycteria leucocephala by a Spotted Eagle Aquila species in Sultanpur National Park, Haryana. Indian Birds, 1: 144-145.

Urfi, A.J., Meganathan, T., Kalam, A. and Mahendiran, M. (2005). Nesting of Asian Openbill and other heronry birds at Sultanpur National Park. Indian Birds, 6: 10-11

Urfi, A.J., Meganathan, T. and Kalam, A. (2007). Nesting ecology of the Painted Stork, Mycteria leucocephala at Sultanpur National Park, Haryana, India. Forktail, 23: 150-153.

Whistler, H. (1915). Notes on the birds of Ambala District, Punjab. Part-2. J . Bombay Nat. Soc., 24(1): 172-191.

Whistler, H. (1918). Notes on the birds of Ambala District, Punjab. J. Bombay Nat. Soc., 25(4): 665-681.

Yadav, J.S. and Maleyvar, R.P. (1978). The birds of Haryana. A classified List. J ournal of H aryana studies, 10(1): 37-51.

Yadav, J.S. and Maleyvar, R.P.(1981). The birds of Haryana: a few more spotting. Pavo, 19: 51-55. 